OPEN ACCESS

Edited by:

Johnbosco C. Egbueri, Chukwuemeka Odumegwu Ojukwu

University, Nigeria

Reviewed by:

Orish Ebere Orisakwe,

University of Port Harcourt, Nigeria

Michael Omeka,

University of Calabar, Nigeria

${ }^{*}$ Correspondence: Héctor A. González-Ocampo

hgocampo@yahoo.com

${ }^{\dagger}$ These authors have contributed equally to this work and share first authorship

Specialty section: This article was submitted to Toxicology, Pollution and the Environment

a section of the journal

Frontiers in Environmental Science

Received: 07 September 2021

Accepted: 25 October 2021

Published: 01 December 2021

Citation:

Castro-Elenes $M$,

Rodríguez-Meza GD,

Pérez-González $E$ and González-Ocampo HA (2021) Trace Metal Residues in Swimming Warrior Crab Callinectes bellicosus: $A$ Consumption Risk.

Front. Environ. Sci. 9:772221. doi: 10.3389/fenvs.2021.772221

\section{Trace Metal Residues in Swimming Warrior Crab Callinectes bellicosus: A Consumption Risk}

\author{
Marisol Castro-Elenes, G. Durga Rodríguez-Meza ${ }^{\dagger}$, Ernestina Pérez-González and \\ Héctor A. González-Ocampo *t
}

Instituto Politécnico Nacional - CIIDIR Unidad Sinaloa, Guasave, Mexico

This study was carried out in the Navachiste coastal lagoon, Mexico, surrounded by intensive agricultural and aquaculture activities that cause environmental pollution by the deposition of trace metal residues in the sediments of this coastal lagoon. The trace metals are bioaccumulated by benthic organisms such as the blue swimming warrior crab, Callinectes bellicosus, which inhabits this lagoon and is consumed by humans. Ninety-five C. bellicosus edible tissue samples were collected (April 2014-January 2015). The extraction procedure of the trace metals in edible tissue samples was carried out by acid digestion with nitric acid. Based on the Environmental Protection Agency (EPA) of the United States, two indices were used to measure health risk: the estimated daily intake (EDI) and the target hazard quotient (THQ). The hazard index (HI) was used to calculate the probability of adverse carcinogenic risk and the target hazard quotient per sample $(\mathrm{MHI})$ to calculate the probability of developing a carcinogenic or non-carcinogenic risk. The analysis of variance (ANOVA) showed significant differences among trace metal concentrations $(p<0.01)$, but all trace metal concentrations in the edible tissues of $C$. bellicosus were higher than the maximum residual limits (MRLs). The highest EDI was for $\mathrm{Zn}, \mathrm{Fe}$, and $\mathrm{Cu}$, showing that the consumption of these crabs might represent health risks. The $\mathrm{THQ}>1$ was for $\mathrm{Ni}, \mathrm{Zn}, \mathrm{Cd}$, and $\mathrm{Cu}$, and the $\mathrm{HI}=16$ revealed the risk of $\mathrm{C}$. bellicosus for high-level consumers. The MHI showed that $98 \%$ of samples presented a $T H Q>1$, implying a high rate of bioaccumulation of trace metals by the crabs independent of the sampling site in the NAV. The presence of trace metals in the edible tissue of crabs reflects contamination by trace metals, and the indices results mean that the NAV lagoon is constantly polluted with trace metal residues by neighboring agriculture and aquaculture activities. These trace metal residues are being bioaccumulated in the edible tissues of $C$. bellicosus due to its feeding habits, resulting in a health risk if its consumption is high, including carcinogenic and non-carcinogenic risks.

Keywords: seafood, heavy metal, trace elements, Navachiste, environmental pollution

Abbreviations: NBay, Navachiste Bay, Sinaloa, Mexico; NAV, Navachiste coastal lagoon system; PCA, principal components analysis. 


\section{INTRODUCTION}

The risk of exposure by humans to trace metals has increased significantly in industrial and agricultural regions. Coastal lagoons are some of the areas most impacted by the discharges of these pollutant residues (Pan and Wang, 2012; Meena et al., 2017; Yang et al., 2018). One of these impacted regions is the coastal lagoon system of Navachiste (NAV) located in the southeastern part of the Gulf of California. It is a semiclosed coastal lagoon in a semiarid and subtropical area with sand barrier islands and significant extensions of mangrove areas, columnar cacti, dry deciduous forests, wetlands, and shrublands. NAV is surrounded by the largest agricultural region in Mexico and more than 9,000 ha of shrimp aquaculture farms (Carrasquilla-Henao et al., 2013) that are constantly discharging pollutant residues, such as trace metals, which enter the coastal lagoons (Pan and Wang, 2012; Meena et al., 2017; Yang et al., 2018). Metal residues are found naturally in soils and sediments, but enrichment has been related to agricultural and aquaculture practices (Jalali and Hemati, 2013). NAV is being impacted by the residues drained from the agricultural Guasave Valley (Martínez-Valenzuela et al., 2009) and by the large quantities of fish excrement, uneaten feed, antibiotics, fungicides, and antifouling agents released by the aquaculture activities (Mateo-Sagasta et al., 2018).

Previous studies carried out in NAV have described how trace metal concentrations in its sediments have become bioavailable to marine species (Páez-Osuna and Osuna-Martínez, 2015), including those of commercial interest (Páez-Osuna and Osuna-Martínez, 2015; Góngora-Gómez et al., 2018; DelgadoAlvarez et al., 2019). In the NAV, one of the most important artisanal fisheries is the blue swimming warrior crab (Callinectes bellicosus) which is exported to international markets at up to 13,000 tons year ${ }^{-1}$ (Ortega-Lizárraga et al., 2020).

Due to the commercial importance of C. bellicosus, the increased bioavailability of trace metals in sediments of NAV, and the ability of this crab to induce bioturbation of sediments because of its omnivorous feeding habit that resuspends the metal residues, which, in turn, become bioaccumulated in its tissues, $C$. bellicosus represents a human health risk to consumers. In this sense, monitoring these metal traces in the edible tissue of $C$. bellicosus is a significant concern for health risks. Thus, the main objective of this study was to determine the trace metal residue content in the edible tissue of the C. bellicosus crab to evaluate the carcinogenic and non-carcinogenic risks posed by the consumption of this species.

\section{MATERIAL AND METHODS}

The NAV encloses three lagoons (San Ignacio, Macapule, and Navachiste) located in the southeastern Gulf of California $\left(25^{\circ}\right.$ $27^{\prime} 59^{\prime \prime} \mathrm{N}$ and $\left.108^{\circ} 50^{\prime} 24^{\prime \prime} \mathrm{W}\right)$. Samples were collected during spring, summer, autumn, and winter, with crab traps from April 2014 to January 2015 (Figure 1). The sampling sites were selected based on two characteristics: their proximity to discharge drainages from agricultural, urban, and shrimp farming areas and locations not influenced by any drainage effluents. Water parameters $(\mathrm{pH}$, temperature, salinity, and dissolved oxygen) were recorded with a HANNA $^{\circledR}$ HI-9828 multiparameter (HANNA Instruments, Italy). The samples were packed in polyethylene bags to avoid contamination with trace metal residues of other packing materials, like aluminum foils, and cold stored in a 40-L cooler to delay the oxidation of organic matter in sediments until freezing in the Environmental Contamination Laboratory of the CIIDIR-IPN, Sinaloa Unit.

Ninety-five samples of edible tissues of the crab species $C$. bellicosus were processed. The trace metals were extracted by acid digestion with nitric acid based on the Breder method for the extraction of metal residues in sediments by atomic absorption spectrometric methods and for silicate sediments (Breder, 1982). The muscle tissues of each sample were dehydrated; subsequently, $0.5 \mathrm{~g}$ per sample was supplemented with $5 \mathrm{ml}$ of $\mathrm{HNO}_{3}(65 \%)$ and placed for $4 \mathrm{~h}$ in an aluminum heating block with precise temperature control to dissolve the organic matter strongly adhered to sediments. A similar procedure was performed with $0.5 \mathrm{~g}$ of the sediment that was tested with $5 \mathrm{ml}$ of a $1: 3 \mathrm{HCl}-\mathrm{HNO}_{3}$ mix. This mixture does not decompose the sediment, and high recovery of the metallic elements is achieved, and the extractions are precise in determining metals such as $\mathrm{As}, \mathrm{Cu}, \mathrm{Cr}, \mathrm{Hg}, \mathrm{Mn}, \mathrm{Ni}, \mathrm{Pb}, \mathrm{V}$, and $\mathrm{Zn}$. After digestion, the samples were cooled to room temperature, gauged to $50 \mathrm{ml}$ with deionized water, and transferred to a graduated polypropylene Falcon ${ }^{\circledR}$ tube. A GBC AVANTA ${ }^{\circledR}$, USA, atomic absorption spectrometer, with a programmable air-acetylene flame and hollow cathode lamps, was used to detect and determine trace metals. The precision of the instruments and techniques was adjusted using the TORT-2 lobster hepatopancrea reference material, NRC-CNRC ${ }^{\circledast}$, which was treated like the samples. Six calibration curves $(0.125,0.25$, $0.5,1,2$, and $4 \mathrm{mg} \mathrm{L}^{-1}$ ) were prepared using the standard certified PerkinElmer ${ }^{\circledR}$ solution $(1000 \mathrm{mg} \mathrm{L}-1)$. The limit of detection (LOD) for each metal was calculated using the following equation (INMETRO 2016) (Eq. 1):

$$
\mathrm{LOD}=10 \times \mathrm{S}_{\mathrm{bl}}
$$

where $S_{b l}$ is the standard deviation of 10 control blanks analyzed, in the present report, and the LOD was $0.0158 \mathrm{mg} \mathrm{CaCO}_{3} \mathrm{~L}^{-1}$.

As recommended by the U.S. Environmental Protection Agency of the (USEPA), three indices were used to measure health risks: estimated daily intake (EDI), target hazard quotient (THQ), and hazard index (HI). In this study, we propose the use of the total metal THQ per sample (MTHQ) index. The estimated daily intake (EDI) $\left(\mu \mathrm{g} \mathrm{kg}^{-1} \mathrm{day}^{-1}\right)$ is the exposure to a chemical residue or consumption of a nutrient and was calculated considering the resulting metal concentration, crab consumption, and mean body weight chart for U.S. adults, following the next equation (Eq. 2) (U.S. Environmental Protection Agency, 2013):

$$
E D I=\frac{C_{m} \times F_{I R}}{B W}
$$

Here, $\mathrm{Cm}=$ metal concentration of the sample $\left(\mathrm{mg} \mathrm{kg}^{-1} \mathrm{ww}\right)$; FIR = seafood ingestion rate in the United States $\left(0.227 \mathrm{~g} \mathrm{pers}^{-1}\right.$ day $\left.^{-1}\right)$ 


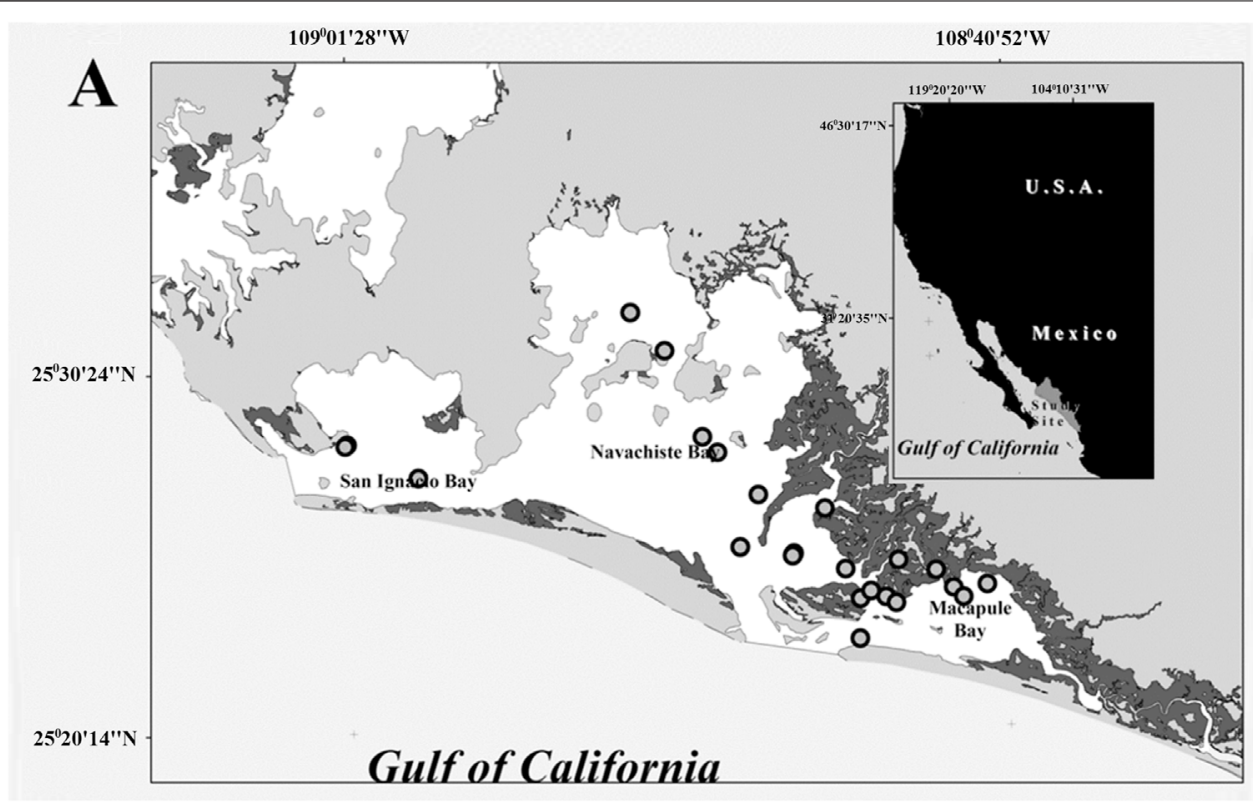

FIGURE 1 | NAV lagoon complex location and C. bellicosus sampling points.

(USEPA, 2000); and BW is the average body weight of adults, which was determined at $70 \mathrm{~kg}$.

The target hazard quotient (THQ) (U.S. Environmental Protection Agency, 2005) is the health risk posed by the swimming warrior blue crab and was calculated based on the following equation (U.S. Environmental Protection Agency, 2018) (Eq. 3):

$$
T H Q=\frac{E F \times E D \times C S \times M C}{B W \times A T \times R_{F D}} \times 10^{-3}
$$

where $E F=$ exposure frequency (350 days year ${ }^{-1}$ ), $E D=$ human exposure duration-70 years (average lifetime), $C S=$ seafood meal size in the United States for average crab consumers $\left(0.227 \mathrm{~g}^{\text {pers }}{ }^{-1}\right.$ day $\left.^{-1}\right), M C=$ metal concentration in one crab edible portion $\left(\mathrm{mg} \mathrm{kg}^{-1}\right.$ ww), $B W=$ adult body weight $(70 \mathrm{~kg}), A T=$ average time $\left(E D \times 365\right.$ days/year), and $R_{F D}=$ oral reference dose $\left(\mathrm{mg} \mathrm{kg}^{-1}\right.$ of body weight per day) (USEPA, 1989; 2000). $R_{F D}$ is an estimate of daily oral exposure to a toxic substance during a lifetime for a human population (Bress, 2009). $R_{F D}$ reported for $\mathrm{Cd}$ and $\mathrm{Pb}$ were 0.0003 and $0.00005 \mathrm{mg} \mathrm{kg}^{-1} \mathrm{day}^{-1}$, respectively (Hassett-Sipple et al., 1997); for $\mathrm{Cu}$, $\mathrm{Fe}, \mathrm{Mn}, \mathrm{Ni}$, and $\mathrm{Zn}$, they were $0.04,0.7,0.024,0.00026$, and $0.3 \mathrm{mg} \mathrm{kg}^{-1}$ day $^{-1}$, respectively (U.S. Environmental Protection Agency, 2018).

The hazard index (HI) is the probability of developing a carcinogenic or non-carcinogenic risk and was calculated to evaluate the risk of all trace metals. It corresponds to the total of calculated THQ trace metal concentrations in all samples and indicates the ratio between exposure and the reference dose as follows (Jović and Stanković, 2014) (Eq. 4):

$$
H I=\sum_{i=1}^{n} T H Q_{i}
$$

where $\mathrm{THQ}_{\mathrm{i}}=$ target hazard quotient of individual trace metals and $n=$ number of examined trace metals (in the present study, $n=7)$. HI, $\leq 1$ means a non-probability of adverse carcinogenic risk; $\mathrm{HI}>1$ indicates a probability of adverse effects, and $\mathrm{HI} \geq 10$ suggests the presence of a high likelihood of chronic risk (Lei et al., 2015).

In the present study, we calculated the target hazard quotient per sample (MHI) to determine the carcinogenic and noncarcinogenic risk per sample as follows (Eq. 5):

$$
M H I=\left(\sum_{i=1}^{n} M_{i} T H Q_{i}\right)
$$

where MiTHQi $=$ is the sum of the target hazard quotient of each trace metal per sample $\mathrm{n}$ (in the present study, $n=95$ ). As in the THQ index, values of $\mathrm{MHI} \leq 1$ mean a non-probability of adverse carcinogenic risk, MHI $>1$ indicates a probability of adverse effects. MHI $\geq 10$ suggests the presence of a high likelihood of chronic risk.

The data were statistically analyzed with SAS $^{\circledR}$ (v. 9) and Statistica $^{\circledR}$ (ver. 7) and $\log _{10}$ transformed for a Kolmogorov-Smirnov $(p>0.05, \alpha=0.05)$ test and ANOVA $(p<0.05, \alpha=0.05)$; when significant differences were detected a post hoc Tukey HSD (Vasavada, 2014) test was applied. Pearson's correlation test $(p<0.05)$ was used for trace metal concentration and weight, size, and physicochemical seawater parameters. A Spearman's correlation, followed by principal components analysis (PCA) $(p<$ 0.05 ), was performed among seasons and physicochemical seawater parameters and trace metal concentrations.

\section{RESULTS AND DISCUSSION}

The weight of crabs ranged from 102 to $386 \mathrm{~g}$ ww $(238.2 \pm 76.7 \mathrm{~g}$ ww), the width and length of shell oscillated from 10.5 to $16.5 \mathrm{~cm}$, 
and $5.5-9 \mathrm{~cm}$, respectively. The trace metal average concentrations $\left(\mathrm{mg} \mathrm{kg}^{-1}\right)$ detected in the 95 edible samples of C. bellicosus were $1.77 \pm 2.98(\mathrm{Cd}), 64.23 \pm 30.94(\mathrm{Cu}), 65.18 \pm$ $35.35(\mathrm{Fe}), 6.0 \pm 4.04(\mathrm{Mn}), 6.34 \pm 3.38(\mathrm{Ni}), 5.27 \pm 2.97(\mathrm{~Pb})$, and $184.37 \pm 76.21(\mathrm{Zn})$. The ranges of trace metal concentrations were for $\mathrm{Cd} 0.073-11.034, \mathrm{Ni} 0.18-12.63, \mathrm{~Pb} 0.88-13.63, \mathrm{Cu}$ 18.15-190.77, Fe 24.57-257.64, Mn 0.024-14.82, and $\mathrm{Zn}$ 77.29-571.20. The concentration sequence of trace metals was $\mathrm{Zn}>\mathrm{Fe}>\mathrm{Cu}>\mathrm{Mn} \approx \mathrm{Ni}>\mathrm{Pb}>\mathrm{Cd}$. Higher concentrations of $\mathrm{Zn}$, $\mathrm{Fe}$, and $\mathrm{Cu}$ could be attributed to agricultural residues. This activity uses formulants that contain glyphosate-based herbicides and other pesticides usually rich in one or more of these metals (Defarge et al., 2018). This suggests that discharges from the surrounding agricultural or aquaculture activities are currently present at the NAV (Martínez-López et al., 2017) increasing after irrigation activities (Páez-Osuna and Osuna-Martínez, 2015). Discharged trace metal residues have been trapped in the NAV sediments, as previously reported (Montes et al., 2012) and bioaccumulated by Callinectes species. As previously reported, the presence of traces of metals in the edible tissue of crabs reflects contamination by metal residues in estuarine ecosystems (Anandkumar et al., 2019; Truchet et al., 2020), as occurring in NAV. Metals ( $\mathrm{Hg}, \mathrm{Zn}, \mathrm{Cd}, \mathrm{Cu}$, and others), metalloids (As), and radioisotope residues are degraded very slowly due to their long geochemical cycle and the increase in disturbances and acceleration of metal residues produced by anthropogenic activities that may be accumulated in the sediments, where they can stay for years (Wuana and Okieimen, 2011), leading to the persistence of toxicants in the environment (Peng et al., 2009). After that, they become bioavailable and are absorbed by marine biota after the irrigation season that begins in October (presowing) and ends in January (Sifuentes et al., 2016). However, more studies must be done to correlate the bioavailability of trace metal concentrations with sedimentation rates, pollutants, and organic matter concentrations in the effluents.

In the NAV system, anthropic source metals are added and dispersed in the lagoon. These anthropic compounds contain $\mathrm{Cd}$ and $\mathrm{Pb}$ impurities, which increase their content in the soil after fertilization application (Wuana and Okieimen, 2011). Local reports indicate that in phosphate fertilizers, the average content of $\mathrm{Pb}$ and $\mathrm{Cd}$ is 10.9 and $10.4 \mathrm{mg} \mathrm{kg}^{-1}$, respectively; for nitrogen fertilizers, $\mathrm{Pb}$ and $\mathrm{Cd}$ contents are $4.7 \mathrm{mg}$ and $2.03 \mathrm{mg} \mathrm{kg}^{-1}$, respectively (Romano Casas et al., 2019). The primary source of phosphorus fertilizers is phosphorite rocks, mainly consisting of apatite naturally enriched by lanthanides such as $\mathrm{Cu}, \mathrm{Ni}$, and $\mathrm{Zn}$ (Boumaza et al., 2021). These fertilizers, widely used in Sinaloa, are an essential source of diverse elements in soils. In the region, Cd concentrations are low during the spring, with a slight increase in late summer (Romano Casas et al., 2019). These concentrations could be associated with the indiscriminate use/application of fertilizers that, consequently, drain their residues into the NAV and with primary productivity in the water column, the content of organic matter, clay minerals, and hydrothermal events during its formation.
In the present study, the highest concentrations of metals in sediments and tissues of C. bellicosus were found in April, 2 months after the irrigation season, and in sites nearby or in front of the effluents of wastewater from agriculture or aquaculture activities (sites 2, 3, 4, and 5; Figure 2). It has been observed that an increase in trace metal concentrations begins in the spring (dry) and decreases during the summer (wet) and winter (dry), 2-3 months after agricultural or aquaculture wastewater discharges. During the sedimentation process that can take months, trace metal residues are precipitated to the sediments (Saleh, 2021), and their composition varies by resuspension, biogeochemical interactions with sourcing areas, sediment resuspension transport, depositional rates, and diagenesis processes (Spagnoli and Bergamini, 1997; Spagnoli et al., 2021). Griboff et al. (2020) found correlations between some trace metals and the dry seasons, resembling the results found in this work. The accumulation of metal residues in sediments of an aquatic system contributes to their dispersion and bioavailability to marine biota. These dispersions and bioavailability in the NAV increase with the presowing irrigation from October to January in the Guasave valley (Sifuentes et al., 2016).

The presence of trace metals in the edible tissue of biota, and sediments from the NAV have been previously reported (Orduna-Rojas and Longoria-Espinoza, 2006; Reyes-Montiel, 2013; Aguilar-Gonzalez et al., 2014; Granados-Galván et al., 2015; Páez-Osuna and Osuna-Martínez, 2015). Trace metals have an affinity with organic matter, which is incorporated into the marine sediments of coastal lagoons, such as NAV. In the sediments, these trace metals become bioavailable, and bioaccumulation of metals in C. bellicosus could be related to the feeding habits of the species, the rates of absorption and depuration, the environmental conditions, the bioavailability of the metals, the fine texture of the sediments, $\mathrm{CaCO}_{3}$ content, and organic matter content (Jerome and Chukwuka, 2016; Álvaro et al., 2016; Chuan et al., 2017; Genç and Yilmaz, 2017; Çoğun et al., 2017; Annabi et al., 2018; Baki et al., 2018; Durmus et al., 2018; Saber et al., 2018; Hao et al., 2019; Cruz et al., 2021). C. bellicosus is an omnivorous species that induces bioturbation of sediments by mixing and resuspending the organic matter associated with the sediment, improving the bioavailability of trace metals (Andrade et al., 2020; Truchet et al., 2020), which are ingested and bioaccumulated in different tissues of this crab.

In invertebrates, the molting stage occurs as a growth process. It is a critical moment in the detoxification of bioaccumulated metals (Anandkumar et al., 2019) that depends mainly on the presence of metallothioneins. Metallothioneins play a role in detoxifying trace metals in estuarine crabs that can translocate and bioaccumulate in the tissues (Truchet et al., 2020). However, the concentrations of these proteins are related to changes in natural factors, such as salinity, weight, or sex (Legras et al., 2000). Indeed, for C. bellicosus, it is recommended to carry out studies regarding the concentration of these molecules and perform a correlation with the physiochemical seawater parameters to elucidate whether trace metal concentrations in C. bellicosus tissues are 
TABLE 1 | Average metal content $\left(\mathrm{mg}^{-1} \mathrm{~kg}^{-1}\right)$ in muscle tissue of different crab species.

\begin{tabular}{|c|c|c|c|c|c|c|c|c|c|c|}
\hline Element & $\begin{array}{c}\text { C. } \\
\text { bellicosus } \\
\text { (this } \\
\text { study) }\end{array}$ & $\begin{array}{c}P . \\
\text { marmoratus }^{a}\end{array}$ & $\begin{array}{c}P . \\
\text { segnis }^{\mathrm{b}}\end{array}$ & $\begin{array}{c}\text { C. } \\
\text { sapidus }\end{array}$ & $\begin{array}{c}\text { C. } \\
\text { amnicola }^{f}\end{array}$ & $\begin{array}{c}P . \\
\text { sanguinolentus }\end{array}$ & $\begin{array}{c}T . \\
\text { crenata }\end{array}$ & $\begin{array}{c}\text { M. } \\
\text { victor }\end{array}$ & $\begin{array}{c}E . \\
\text { verrucosa }\end{array}$ & $\begin{array}{l}\text { Scylla } \\
\text { spp. }\end{array}$ \\
\hline $\mathrm{Cu}$ & $64.23 \pm 30.94$ & $172.91 \pm 7.88$ & $206.45 \pm 71.88$ & $\begin{array}{l}9.26 \pm \\
0.53^{\mathrm{c}} \\
18.214 \pm \\
2.60^{\mathrm{d}} \\
2.8 \pm 0.21^{\mathrm{e}}\end{array}$ & $9.48-12.76$ & $17.205 \pm 0.53^{g}$ & $\begin{array}{l}30.735 \pm \\
0.36^{\mathrm{g}}\end{array}$ & $\begin{array}{l}11.4 \pm \\
0.44^{\mathrm{g}}\end{array}$ & $42.2 \pm 4.8^{h}$ & $65.8^{i}$ \\
\hline $\mathrm{Cd}$ & $1.77 \pm 2.98$ & $1.22 \pm 1.13$ & $0.21 \pm 0.03$ & $\begin{array}{l}1.23 \pm \\
0.19^{\mathrm{C}} \\
0.161 \pm \\
0.24^{\mathrm{d}} \\
0.313 \pm \\
0.048 \mathrm{SE}^{\mathrm{e}}\end{array}$ & $0.16-0.46$ & $19.48 \pm 0.06^{9}$ & $\begin{array}{l}12.1 \pm \\
0.29^{9}\end{array}$ & $\begin{array}{l}8.03 \pm \\
0.29^{9}\end{array}$ & & $0.17^{i}$ \\
\hline $\mathrm{Fe}$ & $65.18 \pm 35.35$ & $658.33 \pm 0.1$ & $85.05 \pm 18.58$ & $\begin{array}{l}120.64 \pm \\
0.81^{e}\end{array}$ & & $29.56 \pm 1.71^{9}$ & $\begin{array}{l}168.62 \pm \\
1.68^{\mathrm{g}}\end{array}$ & $\begin{array}{l}69.9 \pm \\
2.5^{9}\end{array}$ & $81.68 \pm 5.32^{h}$ & \\
\hline $\mathrm{Ni}$ & $6.34 \pm 3.38$ & $5.56 \pm 0.80$ & & $12.02 \pm$ & & & & & $2.13 \pm 0.19^{h}$ & \\
\hline $\mathrm{Mn}$ & $6.00 \pm 4.04$ & $36.42 \pm 11.05$ & $0.41 \pm 0.08$ & $0.29^{e}$ & & $89.706 \pm 1.26^{9}$ & $\begin{array}{l}10.147 \pm \\
0.2^{\mathrm{g}}\end{array}$ & $\begin{array}{l}6.5 \pm \\
3.48^{9}\end{array}$ & $39 \pm 2.9^{h}$ & \\
\hline $\mathrm{Pb}$ & $5.27 \pm 2.97$ & 0.38 & $0.4 \pm 0.17$ & $\begin{array}{l}2.66 \pm \\
0.23^{\mathrm{C}} \\
1.208 \pm \\
0.13^{\mathrm{d}}\end{array}$ & $1.48 \pm 3.17$ & $<0.06^{9}$ & $<0.06^{\mathrm{g}}$ & $<0.06^{\mathrm{g}}$ & & $0.20^{i}$ \\
\hline $\mathrm{Zn}$ & $184.37 \pm 76.21$ & $146.19 \pm 6.1$ & $590.04 \pm 196.9$ & $\begin{array}{l}28.71 \pm \\
2.23^{\mathrm{C}} \\
43.98 \pm \\
3.44^{\mathrm{d}} \\
11.197 \pm \\
0.77^{\mathrm{e}}\end{array}$ & $\begin{array}{l}2.21-3.65^{f} \\
16.71 \pm 0.77\end{array}$ & $47.37 \pm 0.37^{g}$ & $\begin{array}{l}61.921 \pm \\
0.43^{9}\end{array}$ & $\begin{array}{l}22.6 \pm \\
0.2^{9}\end{array}$ & $284.85 \pm 12.9^{h}$ & $175^{i}$ \\
\hline
\end{tabular}

Bold data indicate lower trace metal concentrations than those detected in the present study.

aÁlvaro et al. (2016).

${ }^{b}$ Annabi et al. (2018).

${ }^{c}$ Coğun et al. (2017).

${ }^{d}$ Gençand Yilmaz (2017).

eSaber et al. (2018).

'Jerome and Chukwuka (2016).

${ }^{g}$ Baki et al. (2018).

${ }^{h}$ Durmus et al. (2018).

'Chuan et al. (2017).

affected. The crab C. bellicosus showed higher $\mathrm{Cu}, \mathrm{Pb}$, and $\mathrm{Zn}$ traces than other estuarine crabs (Table 1). Higher trace metal concentrations in tissues indicate a more significant human disturbance of aquatic systems (Chuan et al., 2017; Genç and Yilmaz, 2017; Baki et al., 2018; Saber et al., 2018). In this sense, the agriculture and aquaculture activities and the increased number of sailing vessels and artisanal outboard fishing in the NAV (Carrasquilla-Henao et al., 2013; Aguilar-Gonzalez et al., 2014) are increasing the bioavailability of trace metals. This correlation of bioavailability and human pollution sources has been previously described. Hamed and Emara (2006) reported high $\mathrm{Cu}, \mathrm{Zn}, \mathrm{Pb}, \mathrm{Cd}, \mathrm{Cr}, \mathrm{Ni}, \mathrm{Fe}$, and $\mathrm{Mn}$ in Patella caerulea tissue in the Suez Canal. Bazzi (2014) determined that in sediments and marine organisms of the Gulf of Chabahar, the highest values of $\mathrm{Zn}, \mathrm{Pb}$, and $\mathrm{Cu}$. In both studies, as in the present, a correlation was found between trace metal concentrations in organisms and human activities, such as shipping, marine transportation, fisheries, and drainage. This higher concentration of $\mathrm{Pb}$ in C. bellicosus could be explained by the potential use of glyphosate-based pesticides in the region
(Balderrama-Carmona et al., 2020), which includes Pb in their formulation (Defarge et al., 2018), and its bioavailability could be increased by the constant wastewater discharges from urban and agricultural areas into the NAV (Álvaro et al., 2016). Zn has been reported to have a high affinity for organic carbon in sediments (Cyriac et al., 2021) and is an essential component of the reproductive coenzymes in the genus Callinectes (Çoğun et al., 2017). In this report, the concentration of $\mathrm{Zn}$ and the higher concentrations of $\mathrm{Cu}$ confirm the relevance of these elements in the metabolism of estuarine crabs (Anandkumar et al., 2019) like C. bellicosus. In addition, the high concentration of $\mathrm{Zn}$ and $\mathrm{Cu}$ (and the other trace metals) could also be attributed to the high phosphorus, urea, and TSS concentrations that have been reported in the area from April to November drained by agriculture and shrimp aquaculture (Martínez-López et al., 2017; Góngora-Gómez et al., 2018).

Among seasons, Spearman's correlation revealed no significant differences $(p<0.05)$ between trace metals and $\mathrm{pH}$ in the spring, salinity, and temperature in the winter (Table 2). 
TABLE 2 | Pearson's correlation results of the trace metal concentration in the edible tissue of $C$. bellicosus and the seawater physicochemical parameters of salinity (\%o), $\mathrm{pH}$, conductivity $(\sigma)$, and temperature $\left(\mathrm{T}^{\circ} \mathrm{C}\right)$.

\begin{tabular}{lcccc}
\hline Trace metal & \% & $\mathbf{p H}$ & $\boldsymbol{\sigma}$ & $\mathbf{T}^{\circ} \mathbf{C}$ \\
\hline $\mathrm{Cu}$ & -0.1 & -0.2 & -0.3 & 0.2 \\
$\mathrm{Fe}$ & 0.1 & -0.1 & 0.1 & -0.1 \\
$\mathrm{Mn}$ & 0.5 & 0.1 & 0.4 & -0.2 \\
$\mathrm{Zn}$ & 0.1 & 0.0 & 0.0 & -0.1 \\
$\mathrm{Cd}$ & 0.2 & -0.1 & -0.9 & -0.1 \\
$\mathrm{Ni}$ & 0.4 & -0.2 & 0.3 & -0.1 \\
$\mathrm{~Pb}$ & -0.1 & 0.1 & 0.1 & 0.3
\end{tabular}

Principal components analysis showed that Mn concentration, conductivity $(\sigma)$, and salinity (S\%o) were negatively correlated. Summer $\mathrm{Pb}$ concentrations showed a negative correlation with temperature (Figure 3). Associations of $\mathrm{Mn}$ and $\mathrm{Ni}$ were revealed with conductivity, $\mathrm{pH}$, and salinity in the spring and late autumn and between $\mathrm{Pb}$ and temperature in the summer. About weight and trace metal concentrations, a significantly low mean negative correlation $(p<0.01)$ was determined between $\mathrm{Zn}$ and weight $(r=$ $-0.4)$. The rest of the trace metals showed a non-significant correlation with weight. After the PCA per season $(p<0.05)$, the spring $\mathrm{Ni}$ concentrations were high and low negative with $s$ and $\mathrm{pH}$, respectively. The first two principal components of the multivariate analysis explained $95 \%$ of the variance (Figure 2 ).

Metal concentrations in the edible tissue of $C$. bellicosus from the NAV revealed the presence of trace metals that could pose a risk if higher concentrations and portions are consumed. ANOVA showed significant differences among trace metal concentrations $(p<0.01)$. At a consumption rate of $0.227 \mathrm{~g}^{-1} \mathrm{day}^{-1}$, the average of all trace metal concentrations in the present study was higher than the

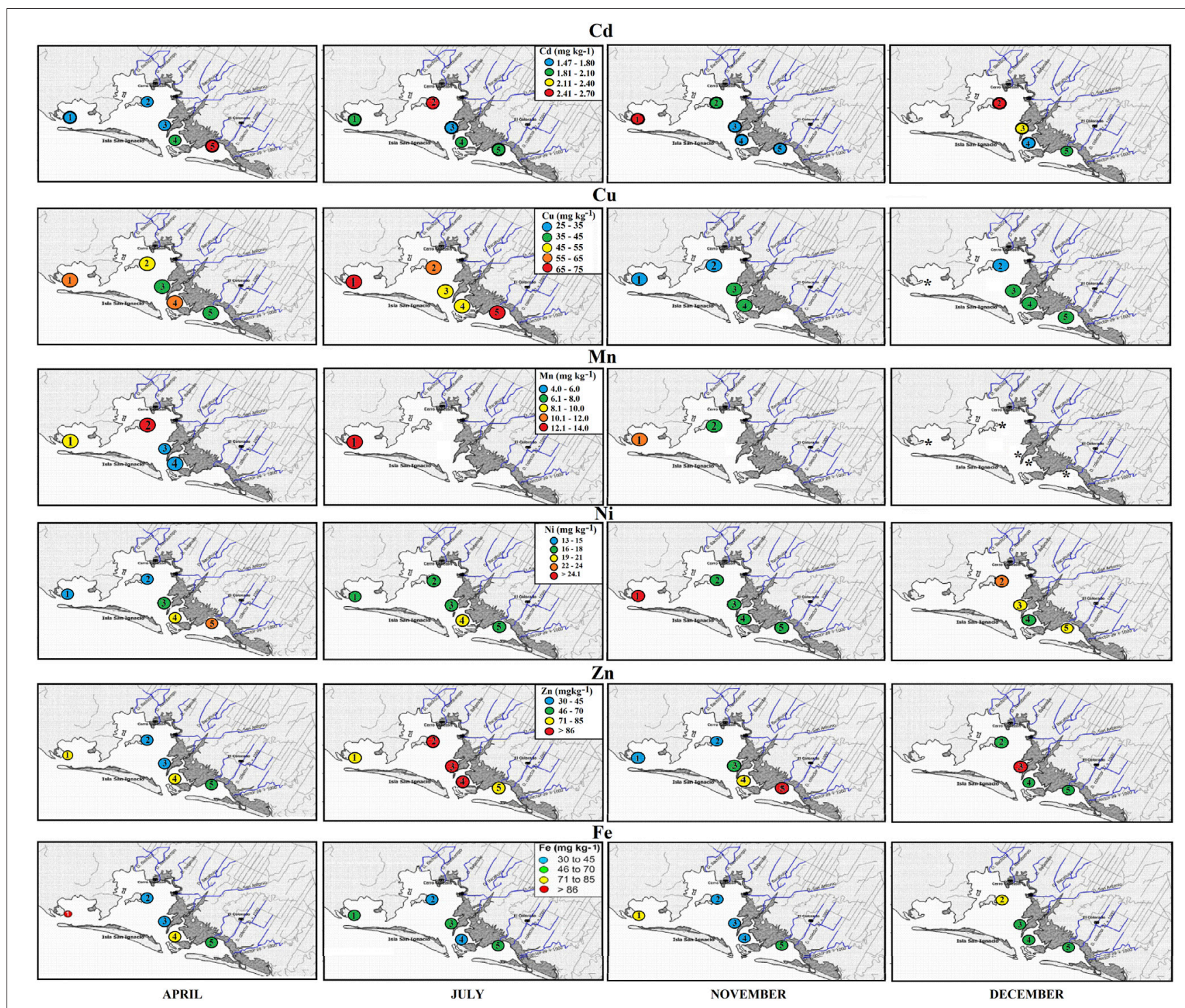

FIGURE 2 | Average trace metal concentration in the edible tissue of C. bellicosus from the collecting sites in the NAV complex, Mexico. 


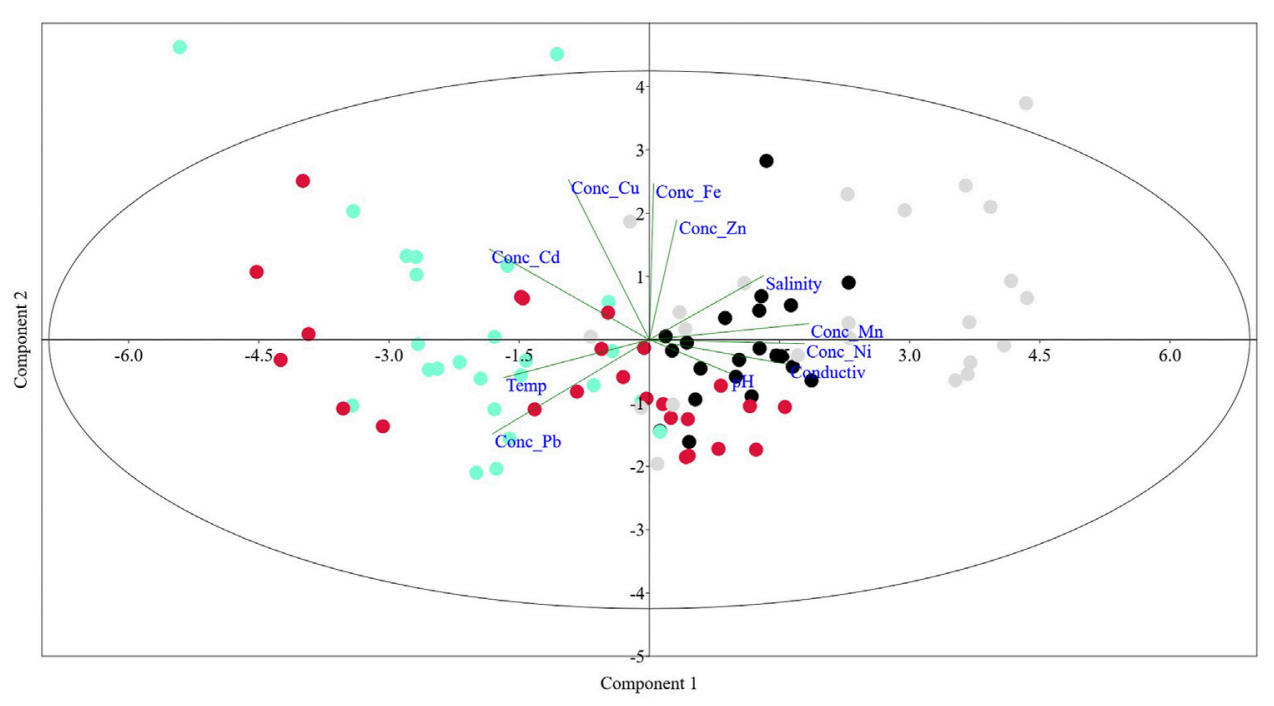

FIGURE 3 | PCA correlation between water physicochemical parameters and trace metals in the edible tissue of $C$. bellicosus from the NAV complex, Mexico.

maximum residual limits (MRLs) delineated by the European Union (EC, 2008), and the United States Food and Drug Administration (National Shellfish Sanitation Program, 2007). The MRLs (in $\mathrm{mg} \mathrm{kg}^{-1} \mathrm{dw}$ ) in edible tissues of crustaceans for the EU and the United States are, respectively, for $\mathrm{Cd}$ of 0.5 and 3.0; for $\mathrm{Ni}$ of 2.8 and 70; and for $\mathrm{Pb}$ of 0.5 and 1.5; whereas for $\mathrm{Cu}, \mathrm{Fe}, \mathrm{Mn}$, and $\mathrm{Zn}$, no records of allowable limits were found. For sediment reference, the Canadian Sediment Quality Guidelines for the Protection of Aquatic Life reference (Canadian Council of Ministers of the Environment, 1999) were used. Fe, Mn, and $\mathrm{Zn}$ were abundant elements and presented the following order of concentration: $\mathrm{Fe}>\mathrm{Mn}>\mathrm{Zn}>\mathrm{Pb}>\mathrm{N}>\mathrm{Cu}$. The primary source of the first element's contribution is weathering of the rocks in the drainage basin. A local report by the Consejo de Recursos Minerales (1991) indicates mineral deposits of $\mathrm{Au}, \mathrm{Ag}, \mathrm{Zn}, \mathrm{Pb}$, $\mathrm{Cu}$, and some of $\mathrm{Fe}, \mathrm{Ni}, \mathrm{Co}, \mathrm{Bi}$, and ferriferous deposits constituted by $\mathrm{Fe}_{3} \mathrm{O}_{4}(72 \%$ of $\mathrm{Fe})$. Iron is present in sediments as iron oxyhydroxides that influence the release of other elements in response to $\mathrm{pH}$ changes, affecting the adsorption or desorption of other metals (Queiroz et al., 2021). Correlation coefficients $\left(r^{2}\right)$ indicated positive values mainly between Fe and $\mathrm{Zn}(0.8), \mathrm{Fe}$ and $\mathrm{Mn}(0.6), \mathrm{Mn}$ and $\mathrm{Ni}(0.70)$, and $\mathrm{Mn}$ and $\mathrm{Cu}(0.8)$, indicating the influence of Fe and $\mathrm{Mn}$ oxides on the release of elements. Fe and $\mathrm{Mn}$ oxides exert control on the adsorption or coprecipitation of elements in sediments (Turner, 2000) in the lagoon system. These properties during seasonal rains, irrigation in agricultural fields, water exchange in aquaculture farms, and others probably contribute to the flow of these inorganic and organic components in the system, thus modifying the natural conditions and bioaccumulation in organisms.

The enrichment factor (EF) and the geoaccumulation index (Igeo) data of ISQG, the continental crust content (Taylor,
1964), preindustrial levels, and Fe as a normalizing element (Salomons and Förstner, 2012) were used as references (Appendix 1). The geochemical index indicated $\mathrm{Pb}$ as uncontaminating to moderately contaminating in January (2017) and Cd as moderately contaminating in April (2016). On the other hand, the enrichment factor presented a similar condition to that of $\mathrm{Cd}$, revealing a severe enrichment of sediments, and $\mathrm{Pb}$ as moderately severe to moderately enriched (Table 3). The normalized data of the other elements indicated a lower enrichment and related them with natural sources in the system.

Regarding the risk assessment, the mean EDI values ( $\mu \mathrm{g}$ $\mathrm{kg}^{-1}$ bw d ${ }^{-1}$ ) of the selected metals ranged from 0.005 to 0.537 in the following sequence: $\mathrm{Zn}>\mathrm{Fe}>\mathrm{Cu}>\mathrm{Ni}>\mathrm{Mn}>\mathrm{Pb}>\mathrm{Cd}$. The highest EDI was for $\mathrm{Zn}, \mathrm{Fe}$, and $\mathrm{Cu}(0.54,0.19$, and $0.19 \mu \mathrm{g} \mathrm{kg}^{-1} \mathrm{day}^{-1}$, respectively); $\mathrm{Zn}, \mathrm{Cu}$, and $\mathrm{Cd}$ were above the acceptable daily intake consumption. In contrast, $\mathrm{Ni}$ and Mn were similar to reference values (FAO and WHO, 2013), at a rate of $0.227 \mathrm{~g}^{-1} \mathrm{day}^{-1}$, and represent a low concentration for the portion established for consumption of trace metals in the $C$. bellicosus edible tissue $(\mathrm{EDI}<1)$. The average THQ ranged between 0.03 and 6.32 . $\mathrm{Zn}, \mathrm{Cu}$, and $\mathrm{Cd}$ were the trace metals with a THQ $>1(7.68,4.74$, and 1.76 , respectively), turning these ratios into an exposure risk to trace metals in the edible tissue of the blue swimming warrior crab. The values of $\mathrm{HI}>1$ represent a potential exposure to trace metals and adverse effects (Jerome and Chukwuka, 2016; Genç and Yilmaz, 2017; Baki et al., 2018). In the present study, the $\mathrm{HI}=$ 16.11 showed a potential exposure to trace metals in the edible tissue of C. bellicosus (Table 4). The MHI for each sample showed that 93 samples (98\%) exhibited an MHI > 1, indicating a potential carcinogenic or non-carcinogenic health risk of $C$. bellicosus edible tissue consumption (Figure 4). 
TABLE 3 | Enrichment factor and the geoaccumulation index of trace metals in sediment samples of the Navachiste coastal lagoon system, Mexico.

\begin{tabular}{|c|c|c|c|c|c|c|c|}
\hline & $\mathrm{Cu}$ & $\mathrm{Fe}(\%)$ & Mn & $\mathrm{Zn}$ & Cd & $\mathrm{Ni}$ & $\mathbf{P b}$ \\
\hline April-16 & $7.0 \pm 2.3$ & $1.6 \pm 0.2 \%$ & $228.2 \pm 73.6$ & $50.2 \pm 54.4$ & $0.97 \pm 0.49$ & $10.0 \pm 3.7$ & $9.0 \pm 4.2$ \\
\hline Jan-17 & $2.33 \pm 1.6$ & $1.8 \pm 0.3 \%$ & $286.1 \pm 47.0$ & $50.9 \pm 9.3$ & - & $12.5 \pm 1.6$ & $24.6 \pm 8.4$ \\
\hline April-17 & $6.2 \pm 2.7$ & $1.94 \pm 0.25 \%$ & $295.5 \pm 55.6$ & $48.35 \pm 7.6$ & - & $6.6 \pm 2.6$ & 9.9 \\
\hline Bazzi (2014) Inv & $21.85-46.8$ & $14.2-53.5$ & $43.2-84.4$ & $16.2-43.1$ & $0.4-0.8$ & $11.7-26.4$ & 13.9-28.2 \\
\hline Bazzi (2014) Ver & $10.97-54.76$ & $12.8-52.1$ & $46.9-89.1$ & $18.8-40.1$ & $0.2-0.5$ & $8.3-28.7$ & $10.7-25.6$ \\
\hline Laguna Unare, Venezuela (Marquez) & 41.1 & $1.56 \%$ & 516.4 & 127.5 & 1.51 & 52.4 & 29 \\
\hline ISQG $^{a}$ & 18.7 & - & - & 124 & 0.7 & - & 30.2 \\
\hline SQS2 & 390 & - & - & 410 & 5.1 & - & 450 \\
\hline TEL2 & 18.7 & - & - & 124 & 0.6 & 15.9 & 30.2 \\
\hline $\mathrm{PEL}^{\mathrm{a}}$ & 108 & - & - & 271 & 4.2 & 42.8 & 112 \\
\hline ERL2 & 34 & - & - & 150 & 1.2 & 20.9 & 46.7 \\
\hline ERM2 & 270 & - & - & 410 & 9.6 & 51.6 & 218 \\
\hline Continental crust (Taylor, 1964) & 55 & $5.6 \%$ & 950 & 70 & 0.2 & 75 & 12.5 \\
\hline Sadiq (1992) ${ }^{\mathrm{b}}$ Ref & $<10$ & - & - & $<110$ & $<1$ & $<10$ & $<5$ \\
\hline Salomons and Forstner (1984) ${ }^{\mathrm{C}}$ & 45 & 47000 & 600 & 95 & 0.2 & 68 & 20 \\
\hline
\end{tabular}

aInterim marine sediments quality guidelines (Canadian sediment quality guidelines for the protection of aquatic life) (ISQG, Interim sediment quality guideline; PEL, Probable effect level). ${ }^{b}$ Non-contaminated sediments Marquez et al. (2008) TEL.

TEL2, threshold effect levels. Concentrations below TEL are not associated with any adverse biological effect. Between TEL and PEL, an adverse biological effect can occur occasionally and frequently above PEL. SQS, quality standards of marine sediments. The quality criterion corresponding to sediments neither related with adverse effects on biological resources, including acute and chronic, nor significant risks for human health WAC, 1995; cited in Fuentes-Hernandez et al., 2019). ERL, low effects interval; ERM, moderate effect interval.

${ }^{c}$ Preindustrial data, from Salomons \& Forstner (2012).

TABLE 4 | Average concentration of trace metals, reference dose (RfD), non-carcinogenic health risk (THQ), and hazard risk (HI) in the edible tissue of $C$. bellicosus from the Navachiste coastal lagoon system in Mexico.

\begin{tabular}{|c|c|c|c|c|}
\hline Trace metal & Concentration $\left(\mathrm{mg} \mathrm{kg}^{-1}\right) M \pm S D$ & $\mathrm{RfD}\left(\mathrm{mg} \mathrm{kg}{ }^{-1} \mathrm{day}^{-1}\right.$ ) & (THQ) & EDI \\
\hline $\mathrm{Cu}$ & $64.23 \pm 30.94$ & $0.04^{\mathrm{a}}$ & 5.29 & 0.18723 \\
\hline $\mathrm{Cd}$ & $1.77 \pm 2.98$ & $0.001^{b}$ & 5.13 & 0.00535 \\
\hline $\mathrm{Fe}$ & $65.18 \pm 35.35$ & $0.7^{\mathrm{a}}$ & 0.30 & 0.18999 \\
\hline $\mathrm{Mn}$ & $6.00 \pm 4.04$ & $0.024^{a}$ & 0.75 & 0.01790 \\
\hline $\mathrm{Ni}$ & $6.34 \pm 3.38$ & $0.02^{a}$ & 1.01 & 0.01847 \\
\hline $\mathrm{Pb}$ & $5.27 \pm 2.97$ & $0.5^{\mathrm{c}}$ & 0.03 & 0.01502 \\
\hline $\mathrm{Zn}$ & $184.37 \pm 76.21$ & $0.3^{\mathrm{a}}$ & 2.15 & 0.53741 \\
\hline Hazard Index (HI) & 14.74 & $\sum \mathrm{THQ}$ & 10.72 & \\
\hline
\end{tabular}

aHassett-Sipple et al. (1997).

${ }^{b}$ U.S. Environmental Protection Agency (2018).

'Limit of lead content in white edible tissues of crustaceans (European Commission, 2014).

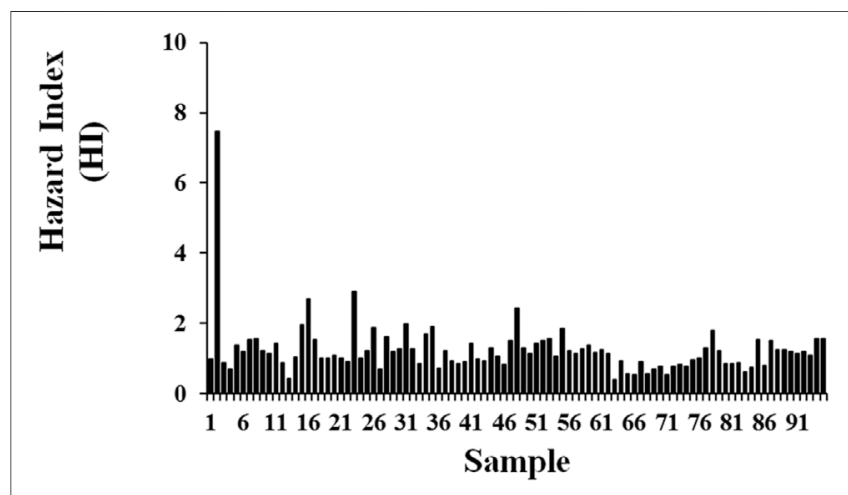

FIGURE 4 | HI per sample of metal residues in the edible tissue of $C$. bellicosus from the NAV complex, Mexico.

\section{CONCLUSION}

The metal residue concentrations in the edible tissue of $C$. bellicosus from the NAV complex were above the maximum allowed metal concentrations in crabs for consumption. Consumption of the edible tissue of $C$. bellicosus from the NAV reveals a risk hazard, including carcinogenic or noncarcinogenic risks. The constant drains from the agricultural Guasave Valley and aquaculture activities after irrigation or wastewater drainage maintain trace metal bioavailability and uptake by the lagoon biota, including the C. bellicosus crab species. Pollution from human activities has been reported for a long time. Findings from the present study confirm the lack of strategies to reduce or avoid the discharge of these pollutants into the lagoon or the use of banned pesticides and fertilizers, whose residues are being discharged into the NAV lagoon complex. 
According to the estimated daily intake (EDI), target hazard quotient (THQ), hazard index (HI), and THQ per sample (MHI), the consumption of $C$. bellicosus edible tissue represents a health risk at a rate of $0.227 \mathrm{~g}^{-1} \mathrm{day}^{-1}$ consumption. This risk would be intensified if the consumption rate increases above $1.2 \mathrm{~g}^{-1}$ day $^{-1}$ pers $^{-1}$.

\section{DATA AVAILABILITY STATEMENT}

The raw data supporting the conclusion of this article will be made available by the authors, without undue reservation.

\section{REFERENCES}

Aguilar-gonzález, M. E., Luna-gonzález, A., Aguirre, A., Zavala-Norzagaray, A. A., Mundo-Ocampo, M., and González-ocampo, H. A. (2014). Perceptions of fishers to Sea Turtle Bycatch, Illegal Capture and Consumption in the San Ignacio-Navachiste-Macapule Lagoon Complex, Gulf of California, Mexico. Integr. Zoolog. 9, 70-84. doi:10.1111/1749-4877.12024

Álvaro, N. V., Neto, A. I., Couto, R. P., Azevedo, J. M. N., and Rodrigues, A. S. (2016). Crabs Tell the Difference - Relating Trace Metal Content with Land Use and Landscape Attributes. Chemosphere 144, 1377-1383. doi:10.1016/ j.chemosphere.2015.10.022

Anandkumar, A., Nagarajan, R., Prabakaran, K., Bing, C. H., Rajaram, R., Li, J., et al. (2019). Bioaccumulation of Trace Metals in the Coastal Borneo (Malaysia) and Health Risk Assessment. Mar. Pollut. Bull. 145, 56-66. doi:10.1016/ j.marpolbul.2019.05.002

Andrade, V. S., Wiegand, C., Pannard, A., Gagneten, A. M., Pédrot, M., Bouhnik-Le Coz, M., et al. (2020). How Can Interspecific Interactions in Freshwater Benthic Macroinvertebrates Modify Trace Element Availability from Sediment? Chemosphere 245, 125594. doi:10.1016/ j.chemosphere.2019.125594

Annabi, A., Bardelli, R., Vizzini, S., and Mancinelli, G. (2018). Baseline Assessment of Heavy Metals Content and Trophic Position of the Invasive Blue Swimming Crab Portunus Segnis (Forskål, 1775) in the Gulf of Gabès (Tunisia). Mar. Pollut. Bull. 136, 454-463. doi:10.1016/j.marpolbul.2018.09.037

Baki, M. A., Hossain, M. M., Akter, J., Quraishi, S. B., Haque Shojib, M. F., Atique Ullah, A. K. M., et al. (2018). Concentration of Heavy Metals in Seafood (Fishes, Shrimp, Lobster and Crabs) and Human Health Assessment in Saint Martin Island, Bangladesh. Ecotoxicology Environ. Saf. 159, 153-163. doi:10.1016/ j.ecoenv.2018.04.035

Balderrama-Carmona, A. P., Valenzuela-Rincón, M., Zamora-Álvarez, L. A., Adan-Bante, N. P., Leyva-Soto, L. A., Silva-Beltrán, N. P., et al. (2020). Herbicide biomonitoring in agricultural workers in Valle del Mayo, Sonora Mexico. Environ. Sci. Pollut. Res. 27, 28480-28489. doi:10.1007/s11356-01907087-6

Bazzi, A. O. (2014). Heavy Metals in Seawater, Sediments and marine Organisms in the Gulf of Chabahar, Oman Sea. J. Oceanogr. Mar. Sci. 5, 20-29. doi:10.5897/ joms 2014.0110

Boumaza, B., Kechiched, R., and Chekushina, T. V. (2021). Trace Metal Elements in Phosphate Rock Wastes from the Djebel Onk Mining Area (Tébessa, Eastern Algeria): A Geochemical Study and Environmental Implications. Appl. Geochem. 127, 104910. doi:10.1016/j.apgeochem.2021.104910

Breder, R. (1982). Optimization Studies for Reliable Trace Metal Analysis in Sediments by Atomic Absorption Spectrometric Methods. Z. Anal. Chem. 313, 395-402. doi:10.1007/bf00495841

Bress, B. (2009). "Risk Assessment," in Chapter 14 - Risk AssessmentPharmacology. Editors M. Hacker, W. Messer, and K. Bachmann (San Diego: Academic Press), 353-369. doi:10.1016/b978-0-12-369521-5.00014-2

Carrasquilla-Henao, M., González Ocampo, H. A., Luna González, A., and Rodríguez Quiroz, G. (2013). Mangrove forest and Artisanal Fishery in the Southern Part of the Gulf of California, Mexico. Ocean Coastal Manag. 83, 75-80. doi:10.1016/j.ocecoaman.2013.02.019

\section{AUTHOR CONTRIBUTIONS}

All authors listed have made a substantial, direct, and intellectual contribution to the work and approved it for publication.

\section{FUNDING}

This work was supported by the Instituto Politécnico Nacional (Grants: SIP-2012-0079, SIP-2013-0398, SIP-2014-0036, SIP2015-0346, Multidisciplinary SIP-2016-1452) and the FOMIX CONACYT-CAMPECHE (grant number 144280, 2014).

Canadian Council of Ministers of the Environment (1999). in Canadian Sediment Quality Guidelines for the protection of Aquatic Life. Editor C. C. O. M. O. T. Environment (Winnipeg, CA).

Chuan, O. M., Ali, N. a. M., Shazili, N. a. M., and Bidai, J. (2017). Selected Heavy Metals Concentration in Edible Tissue of the Mud Crab, Genus Scylla from Setiu Wetlands, Terengganu. J. Sustainability Sci. Manag. 12, 112-118.

Çoğun, H. Y., Firat, Ö., Aytekin, T., Firidin, G., Firat, Ö., Varkal, H., et al. (2017). Heavy Metals in the Blue Crab (Callinectes sapidus) in Mersin Bay, Turkey. Bull. Environ. Contam. Toxicol. 98, 824-829. doi:10.1007/s00128017-2086-6

Cruz, A. C. F., Pauly, G. F. E., Araujo, G. S., Gusso-Choueri, P., Fonseca, T. G., Campos, B. G., et al. (2021). Metal Bioaccumulation by the Neotropical Clam Anomalocardia Flexuosa to Estimate the Quality of Estuarine Sediments. Bull. Environ. Contam. Toxicol. 107 (1), 106-113. doi:10.1007/s00128-02003062-x

Cyriac, M., Gireeshkumar, T. R., Furtado, C. M., Fathin, K. P. F., Shameem, K., Shaik, A., et al. (2021). Distribution, Contamination Status and Bioavailability of Trace Metals in Surface Sediments along the Southwest Coast of India. Mar. Pollut. Bull. 164, 112042. doi:10.1016/j.marpolbul.2021.112042

Defarge, N., Spiroux de Vendômois, J., and Séralini, G. E. (2018). Toxicity of Formulants and Heavy Metals in Glyphosate-Based Herbicides and Other Pesticides. Toxicol. Rep. 5, 156-163. doi:10.1016/j.toxrep.2017.12.025

Delgado-Alvarez, C., Ruelas-Inzunza, J., Escobar-Sánchez, O., Covantes-Rosales, R., Pineda-Pérez, I. B., Osuna-Martínez, C. C., et al. (2019). Metal Concentrations in Age-Groups of the Clam, Megapitaria Squalida, from a Coastal Lagoon in Mexico: A Human Health Risk Assessment. Bull. Environ. Contam. Toxicol. 103, 822-827. doi:10.1007/s00128-019-02723-w

Durmus, M., Ayas, D., Aydin, M., Kosker, A. R., Ucar, Y., and Ozogul, Y. (2018) The Effects of Sex and Seasonality on the Metal Levels of Warty Crab (Eriphia Verrucosa) in the Black Sea. J. Aquat. Food Product. Tech. 27, 749-758. doi:10.1080/10498850.2018.1485196

Ec (2008). Commission Regulation (EC) No 629/2008 of 2 July 2008 Amending Regulation (EC) No 1881/2006 Setting Maximum Levels for Certain Contaminants in Foodstuffs. Luxemburgo: Official Journal of the European Union.

Fao, and Who (2013). Pesticide Residues In Food And Feed [Online]. Food and Agriculture Organization Af the United Nations - World Health Organization. Available: http://www.codexalimentarius.net/pestres/data/pesticides/index. html?lang=en (Accessed Aug 10th, 2013).

Genç, T. O., and Yilmaz, F. (2017). Metal Accumulations in Water, Sediment, Crab (Callinectes sapidus) and Two Fish Species (Mugil cephalus and Anguilla anguilla) from the Köyceğiz Lagoon System-Turkey: An Index Analysis Approach. Bull. Environ. Contam. Toxicol. 99, 173-181. doi:10.1007/s00128017-2121-7

Góngora-Gómez, A. M., Domínguez-Orozco, A. L., Domínguez-Orozco, A. L., Villanueva-Fonseca, B. P., Muñoz-Sevilla, N. P., and García-Ulloa, M. (2018). Seasonal Levels of Heavy Metals in Soft Tissue and Muscle of the Pen Shell Atrina Maura (Sowerby, 1835) (Bivalvia: Pinnidae) from a Farm in the southeastern Coast of the Gulf of California, Mexico. Rev. Int. Contam. Ambie. 34, 57-68. doi:10.20937/rica.2018.34.01.05

Granados-Galván, I. A., Rodríguez-Meza, D. G., Luna-González, A., and GonzálezOcampo, H. A. (2015). Human Health Risk Assessment of Pesticide Residues in 
Snappers ( Lutjanus ) Fish from the Navachiste Lagoon Complex, Mexico. Mar. Pollut. Bull. 97, 178-187. doi:10.1016/j.marpolbul.2015.06.018

Griboff, J., Wunderlin, D. A., Horacek, M., and Monferrán, M. V. (2020). Seasonal Variations on Trace Element Bioaccumulation and Trophic Transfer along a Freshwater Food Chain in Argentina. Environ. Sci. Pollut. Res. 27, 40664-40678. doi:10.1007/s11356-020-10068-9

Hamed, M. A., and Emara, A. M. (2006). Marine Molluscs as Biomonitors for Heavy Metal Levels in the Gulf of Suez, Red Sea. J. Mar. Syst. 60, 220-234. doi:10.1016/j.jmarsys.2005.09.007

Hao, Z., Chen, L., Wang, C., Zou, X., Zheng, F., Feng, W., et al. (2019). Heavy Metal Distribution and Bioaccumulation Ability in marine Organisms from Coastal Regions of Hainan and Zhoushan, China. Chemosphere 226, 340-350. doi:10.1016/j.chemosphere.2019.03.132

Hassett-Sipple, B., Swartout, J., and Schoeny, R. (1997). "Mercury Study Report to Congress," in Volume 5. Health Effects of Mercury and Mercury Compounds (Research Triangle Park, NC (United State): Environmental Protection Agency).

Jalali, M., and Hemati, N. (2013). Chemical Fractionation of Seven Heavy Metals ( $\mathrm{Cd}, \mathrm{Cu}, \mathrm{Fe}, \mathrm{Mn}, \mathrm{Ni}, \mathrm{Pb}$, and $\mathrm{Zn}$ ) in Selected Paddy Soils of Iran. Paddy Water Environ. 11, 299-309. doi:10.1007/s10333-012-0320-8

Jerome, F. C., and Chukwuka, A. V. (2016). Metal Residues in Flesh of Edible Blue Crab,Callinectes Amnicola, from a Tropical Coastal Lagoon: Health Implications. Hum. Ecol. Risk Assess. Int. J. 22, 1708-1725. doi:10.1080/ 10807039.2016.1219220

Jović, M., and Stanković, S. (2014). Human Exposure to Trace Metals and Possible Public Health Risks via Consumption of Mussels Mytilus galloprovincialis from the Adriatic Coastal Area. Food Chem. Toxicol. 70, 241-251. doi:10.1016/ j.fct.2014.05.012

Legras, S., Mouneyrac, C., Amiard, J. C., Amiard-Triquet, C., and Rainbow, P. S. (2000). Changes in Metallothionein Concentrations in Response to Variation in Natural Factors (Salinity, Sex, Weight) and Metal Contamination in Crabs from a Metal-Rich Estuary. J. Exp. Mar. Biol. Ecol. 246, 259-279. doi:10.1016/s00220981(99)00187-2

Lei, M., Tie, B.-Q., Song, Z.-G., Liao, B.-H., Lepo, J. E., and Huang, Y.-Z. (2015). Heavy Metal Pollution and Potential Health Risk Assessment of white rice Around Mine Areas in Hunan Province, China. Food Sec. 7, 45-54. doi:10.1007/ s12571-014-0414-9

Martínez-López, A., Hakspiel-Segura, C., Escobedo-Urías, D. C., and González-Acosta, B. (2017). Influence of Agriculture and Aquaculture Activities on the Response of Autotrophic Picoplankton in Laguna Macapule, Gulf of California (Mexico). Ecol. Process. 6, 6. doi:10.1186/ s13717-017-0074-8

Martínez-Valenzuela, C., Gomez-Arroyo, S., Villalobos-Pietrini, R., Waliszewski, S., Calderon-Segura, M. E., Felix-Gastelum, R., et al. (2009). Genotoxic Biomonitoring of Agricultural Workers Exposed to Pesticides in the North of Sinaloa State, Mexico. Environ. Int. 35 (8), 1155-1159. doi:10.1016/ j.envint.2009.07.010

Mateo-Sagasta, J., Zadeh, S. M., and Turral, H. (2018). More People, More Food, Worse Water?: A Global Review of Water Pollution from Agriculture. Italy: Rome.

Meena, R. a. A., Sathishkumar, P., Ameen, F., Yusoff, A. R. M., and Gu, F. L. (2017). Heavy Metal Pollution in Immobile and mobile Components of Lentic Ecosystems-A Review. Environ. Sci. Pollut. Res. 25, 1-15. doi:10.1007/ s11356-017-0966-2

Montes, A. M., González-Farias, F. A., and Botello, A. V. (2012). Pollution by Organochlorine Pesticides in Navachiste-Macapule, Sinaloa, Mexico. Environ. Monit. Assess. 184, 1359-1369. doi:10.1007/s10661-011-2046-2

National Shellfish Sanitation Program (2007). "Guide for the Control of Molluscan Shellfish: 2007 Revision," in Section IV. Guidance Documents. Chapter II. Growing Areas. Editor N. S. S. Program (Food and Drug Administration: National Shellfish Sanitation Program).

Orduña-Rojas, J., and Longoria-Espinoza, R. M. (2006). Metal Content in Ulva Lactuca (Linnaeus) from Navachiste Bay (Southeast Gulf of California) Sinaloa, Mexico. Bull. Environ. Contam. Toxicol. 77, 574-580. doi:10.1007/s00128-006-1102-z

Ortega-Lizárraga, G. G., Rodríguez-Domínguez, G., Pérez-González, R., AragónNoriega, E. A., and Mendivil-Mendoza, J. E. (2020). Análisis de la pesquería de jaiba en la región sureste del golfo de California, México. Rbmo 55, 59-67. doi:10.22370/rbmo.2020.55.1.2393
Páez-Osuna, F., and Osuna-Martínez, C. C. (2015). Bioavailability of Cadmium, Copper, Mercury, lead, and Zinc in Subtropical Coastal Lagoons from the Southeast Gulf of California Using Mangrove Oysters (Crassostrea Corteziensis and Crassostrea Palmula). Arch. Environ. Contam. Toxicol. 68, 305-316. doi:10.1007/s00244-014-0118-3

Pan, K., and Wang, W.-X. (2012). Trace Metal Contamination in Estuarine and Coastal Environments in China. Sci. Total Environ. 421-422, 3-16. doi:10.1016/ j.scitotenv.2011.03.013

Peng, Y., Li, X., Wu, K., Peng, Y., and Chen, G. (2009). Effect of an Integrated Mangrove-Aquaculture System on Aquacultural Health. Front. Biol. China 4, 579-584. doi:10.1007/s11515-009-0056-z

Queiroz, H. M., Ying, S. C., Bernardino, A. F., Barcellos, D., Nóbrega, G. N., Otero, X. L., et al. (2021). Role of Fe Dynamic in Release of Metals at Rio Doce Estuary: Unfolding of a Mining Disaster. Mar. Pollut. Bull. 166, 112267. doi:10.1016/ j.marpolbul.2021.112267

Reyes-Montiel, N. J., Santamaría-Miranda, A., Rodríguez-Meza, G. D., GalindoReyes, J. G., and González-Ocampo, H. A. (2013). Concentrations of Organochlorine Pesticides in Fish (Mugil cephalus) From a Coastal Ecosystem in the Southwestern Gulf of California. Biol. Environ. 113B (3), 1-11. doi:10.3318/BIOE.2013.25

Romano Casas, G., Martínez Valenzuela, C., Cuadras Berrelleza, A. A., and Ortega Martínez, L. D. (2019). Pesticides, health and environment impact in Sinaloa (México): implications and challenges in environmental governance [Plaguicidas, impacto en salud y medio ambiente en sinaloa (México): implicaciones y retos en gobernanza ambiental]. Trayectorias Humanas Trascontinentales (4), 103-122. doi:10.25965/ trahs. 1615

Saber, T. M., Khedr, M. H., and Darwish, W. S. (2018). Residual Levels of Organochlorine Pesticides and Heavy Metals in Shellfish from Egypt with Assessment of Health Risks. Slovenian Vet. Res. 55, 101-113. doi:10.26873/svr453-2017

Saleh, Y. S. (2021). Evaluation of Sediment Contamination in the Red Sea Coastal Area Combining Multiple Pollution Indices and Multivariate Statistical Techniques. Int. J. Sediment Res. 36, 243-254. doi:10.1016/j.ijsrc.2020.07.011

Salomons, W., and Förstner, U. (2012). Metals in the Hydrocycle. Springer Berlin Heidelberg.

Sifuentes, E., Macías, J., Ojeda, W., González, V. M., Salinas, D. A., and Quintana, J. G. (2016). Irrigation Management for Potato Crops Based on Climate Variability: Application in Irrigation District 075, Fuerte River, Sinaloa, Mexico [Gestión del riego enfocada a variabilidad climática en el cultivo de papa: aplicación al Distrito de Riego 075, Río Fuerte, Sinaloa, México]. Tecnología y Ciencias Del. Agua 7, 149-168.

Spagnoli, F., and Bergamini, M. C. (1997). Water-sediment Exchange of Nutrients during Early Diagenesis and Resuspension of Anoxic Sediments from the Northern Adriatic Sea Shelf. Water Air Soil Pollut. 99, 541-556. doi:10.1007/bf02406894

Spagnoli, F., De Marco, R., Dinelli, E., Frapiccini, E., Frontalini, F., and Giordano, P. (2021). Sources and Metal Pollution of Sediments from a Coastal Area of the Central Western Adriatic Sea (Southern Marche Region, Italy). Appl. Sci. 11, 1118. doi:10.3390/app11031118

Taylor, S. R. (1964). Abundance of Chemical Elements in the continental Crust: a New Table. Geochimica et Cosmochimica Acta 28, 1273-1285. doi:10.1016/ 0016-7037(64)90129-2

Truchet, D. M., Buzzi, N. S., Simonetti, P., and Marcovecchio, J. E. (2020). Uptake and Detoxification of Trace Metals in Estuarine Crabs: Insights into the Role of Metallothioneins. Environ. Sci. Pollut. Res. 27, 31905-31917. doi:10.1007/ s11356-020-09335-6

Turner, A. (2000). Trace Metal Contamination in Sediments from U.K. Estuaries: An Empirical Evaluation of the Role of Hydrous Iron and Manganese Oxides. Estuarine, Coastal Shelf Sci. 50, 355-371. doi:10.1006/ecss.1999.0573

Usepa (2000). Guidance for Assessing Chemical Contaminant Data for Use in Fish Advisories: Risk Assessment and Fish Consumption Limit. Third ed. Washington, DC: Unites States Environmental Agency.

U.S. Environmental Protection Agency (2005). Human Health Risk Assessment Protocol for Hazardous Waste Combustion Facilities. Office of Solid Waste and Emergency Response, US Environmental Protection Agency. 
U.S. Environmental Protection Agency (2013). "Integrated Risk Information System (IRIS)," in Full List of IRIS Chemicals (U.S.A. Environnmental Protection Agency).

U.S. Environmental Protection Agency (2018). Regional Screening Levels (RSLs)-Generic Tables. USA Environmental Protection Agency.

Usepa (1989). "Risk Assessment Guidance for Superfund," in Vol. I: Human Health Evaluation Manual (Part A) (Washington, DC: EPA).

Vasavada, N. (2014). One-way ANOVA (Analysis of Variance) with post-hoc Tukey HSD (Honestly Significant Difference). Test Calculator for comparing multiple treatments [Online]. Available: http://astatsa.com/OneWay_Anova_with_ TukeyHSD/ (Accessed APR 04, 2016).

Wuana, R. A., and Okieimen, F. E. (2011). Heavy Metals in Contaminated Soils: a Review of Sources, Chemistry, Risks and Best Available Strategies for Remediation. Int. Scholarly Res. Notices 2011, 1-20. doi:10.5402/2011/402647

Yang, Q., Li, Z., Lu, X., Duan, Q., Huang, L., and Bi, J. (2018). A Review of Soil Heavy Metal Pollution from Industrial and Agricultural Regions in China: Pollution and Risk Assessment. Sci. Total Environ. 642, 690-700. doi:10.1016/ j.scitotenv.2018.06.068
Conflict of Interest: The authors declare that the research was conducted in the absence of any commercial or financial relationships that could be construed as a potential conflict of interest.

Publisher's Note: All claims expressed in this article are solely those of the authors and do not necessarily represent those of their affiliated organizations, or those of the publisher, the editors, and the reviewers. Any product that may be evaluated in this article, or claim that may be made by its manufacturer, is not guaranteed or endorsed by the publisher.

Copyright (C) 2021 Castro-Elenes, Rodríguez-Meza, Pérez-González and GonzálezOcampo. This is an open-access article distributed under the terms of the Creative Commons Attribution License (CC BY). The use, distribution or reproduction in other forums is permitted, provided the original author(s) and the copyright owner(s) are credited and that the original publication in this journal is cited, in accordance with accepted academic practice. No use, distribution or reproduction is permitted which does not comply with these terms. 